\title{
ANALISIS RESEPSI “UNSUR KEKERASAN" DALAM VIDEO GAME AMONG US
}

\author{
Ricky Widyananda Putra \\ Desain Komunikasi Visual, Ilmu Komunikasi, Universitas Budi Luhur \\ Jakarta, Indonesia \\ e-mail: rickywidyanandaputra@budiluhur.ac.id
}

\begin{abstract}
Gamers are an important element in video games. Those who encourage game developers to improve the quality of their products. One game that is currently being discussed is Game Among Us, this game is a game inspired by the Werewolf game. In the process of designing and developing a game concept, it is very important to know the users who are expected to play the designed game. One way to get to know the user can be done by studying and researching pre-existing games, so that the user process can understand the meaning of a game, this can be studied with various approaches, one of which is using reception analysis theory. This theory focuses on the activity of interpreting meaning, producing, and experiencing the audience's experience in interaction with media texts. Then those who will be respondents in this research are the creative box community, a game developer community forum that was established in 2016 consisting of students from Budi Luhur University, Jakarta who are directly engaged in producing games and as game media users, where the object of this research is in the form of game media. Therefore, researchers make creative boxes as research subjects by using the object of research, namely the game Among Us. So the goal to be achieved in this research is to find out the meaning of the game Among Us in the form of elements of violence, visualization of characters and backgrounds and storylines using a qualitative descriptive approach.
\end{abstract}

Keywords: Game, Reception, Player, Content

\begin{abstract}
Abstrak
Pemain game merupakan elemen penting dalam video game. Mereka yang mendorong pengembang game untuk meningkatkan kualitas produknya. Salah satu game yang sedang ramai dibicarakan saat ini ialah Game Among Us, game ini merupakan permainan yang terinspirasi oleh permainan Werewolf. Dalam proses perancangan dan pengembangan konsep game sangat penting untuk mengenal user yang nantinya diharapkan akan memainkan game yang dirancang. Salah satu cara dalam mengenal user dapat dilakukan dengan cara mempelajari dan meneliti game yang sudah ada sebelumnya, sehingga dapat diketahui proses user dalam memaknai sebuah game, hal ini dapat digali dengan beragam pendekatan salah satunya dengan menggunakan teori analisis resepsi. Teori ini memfokuskan pada aktifitas interpretif pemaknaan, produksi, dan pengalaman khalayak dalam interaksi dengan teks media. Kemudian yang akan menjadi responden dalam penelitian ini ialah komunitas Kotak kreatif merupakan suatu wadah komunitas game developer yang berdiri pada tahun 2016 yang terdiri dari para mahasiswa Universitas Budi Luhur, Jakarta, yang bergerak secara langsung dalam memproduksi game dan sebagai pengguna media game, di mana objek material dalam penelitian ini beruba media game. Karena hal itu, peneliti menjadikan kotak kreatif sebagai subjek penelitian dengan menggunakan objek penelitian yakni game Among Us. Maka tujuan yang ingin dicapai dalam penelitian ini ialah Untuk mengetahui pemaknaan terhadap game Among Us yakni berupa Unsur kekerasaan, Visualisasi karakter dan background serta alur cerita dengan menggunakan pendekatan deskriptif kualitatif dan teori analisis resepsi untuk mengurai serta memecahkan permasalahan yang ditemukan.
\end{abstract}

Kata Kunci: Game, Resepsi, Pemain, Konten 


\section{PENDAHULUAN}

Pemain game merupakan elemen penting dalam video game. Mereka yang mendorong pengembang game untuk meningkatkan kualitas produknya. Salah satu game yang sedang ramai dibicarakan saat ini ialah Game Among Us, game ini merupakan permainan yang terinspirasi oleh permainan Werewolf. Pada Juni 2018, permainan ini dirilis dalam sistem Android dan iOS. Meskipun awalnya dirilis yang memainkan sedikit, permainan ini mendapatkan peningkatan popularitas pada 2020 , jumlah pemain meningkat dengan cepat dan akhirnya mencapai puncak menjadi 1,5 juta pemain secara bersamaan (https://www.thegamer.com).Game merupakan salah satu aplikasi yang paling banyak dipakai dan dinikmati oleh pengguna media elektronik saat ini, sedangkan Pengertian Game Menurut Wijaya Ariyana \& Arifianto ialah salah satu kebutuhan sekaligus menjadi masalah besar bagi para pengguna komputer, hal tersebut dikarenakan untuk dapat menjalankan suatu game dengan nyaman, maka dibutuhkan spesifikasi komputer yang relatif tinggi dibanding komputer untuk penggunaan biasa (http://www.mandalamaya.com).

Dalam proses perancangan dan pengembangan konsep game sangat penting untuk mengenal user yang nantinya diharapkan akan memainkan game yang dirancang. Salah satu cara dalam mengenal user dapat dilakukan dengan cara mempelajari dan meneliti game-game yang sudah ada sebelumnya, sehingga dapat diketahui proses user dalam memaknai sebuah game, hal ini dapat digali dengan beragam pendekatan salah satunya dengan menggunakan teori analisis resepsi. Reception Study (studi penerimaan) adalah salah satu yang berkembang dikajian budaya (Cultural Studies), yang memfokuskan pada pesan atau wacana komunikasi dan berimplikasi pada khalayak. Analisis resepsi dalam pandangan kajian budaya merujuk pada kajian yang memfokuskan pada aktifitas interpretif pemaknaan (meaning), produksi (production), dan pengalaman (experience) khalayak dalam interaksi dengan teks media. Fokusnya pada proses decoding, interpretasi dan pembacaan sebagai inti dari konseptualisasi analisis resepsi (Hagen, 2000:46).

Selain menggunakan teori analisis resepsi penelitian ini juga nantinya akan dikorelasikan dengan komunikasi visual dan desain komunikasi visual. Adapun yang dimaksud dengan komunikasi visual ialah komunikasi yang menggunakan bahasa visual, dimana unsur dasar bahasa visual adalah segala sesuatu yang dapat dilihat dan dapat dipakai untuk menyampaikan arti makna atau pesan (Kusrianto, 2007:10). Dalam kehidupan nyata, komunikasi secara garis besar bisa terbagi menjadi dua arus besar yaitu komunikasi verbal dan komunikasi non-verbal. Komunikasi verbal secara luas bisa dimaknai sebagai komunikasi yang disampaikan komunikator kepada komunikan dengan cara tertulis (written) atau lisan (oral), sedangkan komunikasi non-verbal adalah proses komunikasi yang tidak menggunakan kata-kata (Putra, 2021:3).

Pada proses penyampaian informasi secara visual, komunikator menggunakan segala sesuatu yang dapat merangsang indra penglihatan dan menyampaikan pesan pada komunikan. Sedangkan yang dimaksud dengan desain komunikasi visual adalah ilmu yang mempelajari konsep komunikasi dan ungkapan daya kreatif, yang diaplikasikan dalam berbagai media komunikasi visual dengan mengolah elemen desain grafis yang terdiri atas gambar (ilustrasi), huruf dan tipografi, warna, komposisi, dan layout. Semua itu dilakukan guna menyampaikan pesan secara visual, audio, dan/atau audio visual kepada target sasaran yang dituju (Sumbo, 2008:24). Pencipta menyimpulkan bahwa Desain komunikasi visual adalah penyampaian pesan dengan bentuk visual melalui berbagai macam media penyampaian pesan, baik berupa gambar, poster, foto, video, maupun animasi.

Seperti yang dijelaskan diatas, maka pada penelitian ini peneliti ingin meneliti media berupa game, yaitu game yang berjudui Among Us. Game karya dari studio game bernama Innersloth. Di mana game ini masuk dalam kategori game multiplayer, yang dapat dimainkan bersama teman maupun publik dengan batasan pemain mulai empat hingga sepuluh pemain tiap permainan. Game Among Us ini menarasikan bagaimana pemain menjadi kru yang menerbangkan pesawat luar angkasa. Dalam permainannya, pemain terbagi menjadi dua kubu yakni Crewmate dan Imposter. Pada penelitian ini yang akan dibahas meliputi unsur kekerasan yang terdapat pada game tersebut, kemudian tampilan visual dalam sebuah game yakni berupa desain karakter, background dan alur cerita. Kemudian yang akan menjadi 
responden dalam penelitian ini ialah komunitas Kotak kreatif merupakan suatu wadah komunitas game developer yang berdiri pada tahun 2016 yang terdiri dari para mahasiswa Universitas Budi Luhur, Jakarta, yang bergerak secara langsung dalam memproduksi game dan sebagai pengguna media game, di mana objek material dalam penelitian ini beruba media game. Karena hal itulah peneliti menjadikan kotak kreatif sebagai subjek penelitian dengan menggunakan objek penelitian yakni game Among Us. Berdasarkan penjelasan pendahuluan diatas, maka tujuan yang ingin dicapai dalam penelitian ini ialah Untuk mengetahui pemaknaan terhadap game Among Us yakni berupa Unsur kekerasaan, Visualisasi karakter dan background serta alur cerita.

\section{METODE PENELITIAN}

Penelitian ini menggunakan metode pendekatan deskriptif kualitatif, menurut Sugiyono (2016:9) metode deskriptif kualitatif adalah metode penelitian yang bertujuan untuk menggambarkan, melukiskan, menerangkan, menjelaskan dan menjawab secara lebih rinci permasalahan yang akan diteliti dengan mempelajari semaksimal mungkin seorang individu, suatu kelompok atau suatu kejadian. Dalam penelitian kualitatif manusia merupakan instrumen penelitian dan hasil penulisannya berupa kata-kata atau pernyataan yang sesuai dengan keadaan sebenarnya. Pendekatan penelitan yang dilakukan dalam penelitian ini adalah pendekatan kualitatif. Penelitian kualitatif yang bermaksud untuk memahami fenomena tentang apa yang dialami oleh subyek penelitian misalnya, perilaku, persepsi, motivasi, tindakan dan lain - lain, secara holistic, dan dengan cara deskripsi dalam bentuk kata - kata dan Bahasa pada suatu konteks yang alamiah dan dengan memanfaatkan metode ilmiah (Moleong, 2004:186).

Penelitian ini menggunakan teori analisis resepsi, untuk menganalisis permasalahan yang ditemukan. Analisis resepsi ialah studi yang berfokus pada penerimaan dan interprestasi khalayak terhadap isi pesan yang disampaikan media. Interprestasi didefinisikan sebagai kondisi aktif seseorang dalam proses berpikir dan kegiatan kreatif pencarian makna. Setiap teks (informasi) yang diberikan oleh media massa akan dimaknai oleh khalayak. Hal ini dikarenakan khalayak tidak diam saja saat menerima pesan dari media tetapi akan secara aktif memaknai isi teks tersebut (Ang dalam Downing, 1990:160-162). Khalayak disini ialah audien yang menerima pesan atau memaknai pesan yang di sampaikan oleh komunikator, adapun pengertian audien ialah "pencipta aktif makna dalam kaitannya dengan teks (pesan), mereka membawa kompetensi cultural yang telah mereka dapatkan untuk dikemukakan dalam teks sehingga audien yang terbentuk berbeda akan mengerjakan makna yang berbeda pula" (Barker, 2011:34). Berdasarkan hal tersebut, maka tujuan yang ingin dicapai dalam penelitian ini ialah Untuk mengetahui pemaknaan terhadap game Among Us pada para pengguna game yang berupa Unsur kekerasaan, Visualisasi karakter dan background serta alur cerita dengan menggunakan pendekatan deskriptif kualitatif dan teori analisis resepsi untuk mengurai serta memecahkan permasalahan yang ditemukan.

\section{HASIL DAN PEMBAHASAN}

\subsection{Deskripsi Data}

Among Us merupakan karya dari studio game bernama Innersloth, Di mana game ini masuk dalam kategori game multiplayer, yang dapat dimainkan bersama teman maupun publik dengan batasan pemain mulai empat hingga sepuluh pemain tiap permainan. Game Among Us ini menarasikan bagaimana pemain menjadi kru yang menerbangkan pesawat luar angkasa. Dalam permainannya, pemain terbagi menjadi dua kubu yakni Crewmate dan Imposter. Pada penelitian ini yang akan dibahas meliputi unsur kekerasan yang terdapat pada game tersebut, kemudian tampilan visual dalam sebuah game yakni berupa desain karakter, background dan alur cerita. Penelitian ini menggunakan pendekatan deskriptif kualitatif, metode deskriptif kualitatif merupakan metode penelitian yang bertujuan untuk menggambarkan, melukiskan, menerangkan, menjelaskan dan menjawab secara lebih rinci permasalahan yang akan diteliti dengan mempelajari semaksimal mungkin seorang individu, suatu kelompok atau suatu kejadian. 
Dalam mengurai permasalahan yang di temukan maka dalam penelitian ini menggunakan teori analisis resepsi, di mana teori ini berfokus pada penerimaan dan interprestasi khalayak terhadap isi pesan yang disampaikan media. Interprestasi didefinisikan sebagai kondisi aktif seseorang dalam proses berpikir dan kegiatan kreatif pencarian makna. Setiap teks (informasi) yang diberikan oleh media massa akan dimaknai oleh khalayak. Responden dalam penelitian ini ialah komunitas Kotak kreatif merupakan suatu wadah komunitas game developer yang berdiri pada tahun 2016 yang terdiri dari para mahasiswa Universitas Budi Luhur, Jakarta. Selain itu kotak kreatif juga sering memenangkan perlombaan tingkat nasional dan menjadi exibitor pada acara game prime 2019 yang diadakan oleh badan ekonomi kreatif (BEKRAF). Karena hal itulah peneliti menjadikan kotak kreatif sebagai subjek penelitian dengan menggunakan objek penelitian yakni game Among Us.

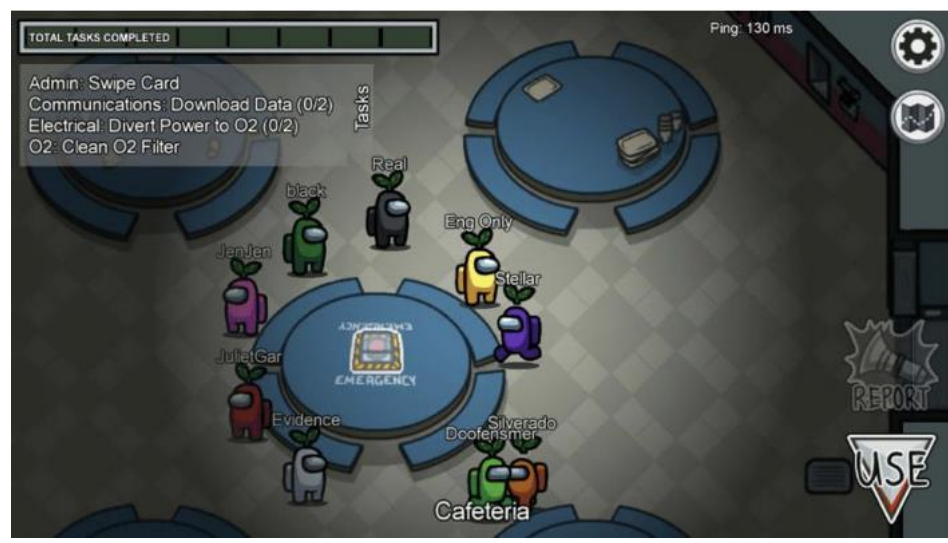

Gambar 1. Tampilan Pada Game Among Us

(Sumber: Game Among Us)

Berdasarkan hasil pemaknaan terhadap game Among Us yakni berupa Unsur kekerasaan, Visualisasi karakter dan background serta alur cerita, maka dapat disimpulkan bahwa game Among Us dapat dipahami oleh khalayak baik dari segi Unsur kekerasaan yang ditampilkan, visualisasi yang diangkat pada desain karakternya dan juga background selain itu dari informasi yang disampaikan yakni berupa alur cerita juga dipahami oleh para informan. Hal ini terlihat dari jumlah total pemaknaan dominan yang paling banyak yakni berjumlah 18 jawaban dari 3 pembahasan.

Tabel 1. Jumlah Pemaknaan Informan dari 3 Pembahasan yakni Unsur Kekerasan, Visualisasi dan Alur Cerita Pada Game Among Us

\begin{tabular}{|c|c|c|c|c|c|c|c|c|c|c|}
\hline & $\begin{array}{l}\text { Info } \\
\text { rma } \\
\text { n1 }\end{array}$ & $\begin{array}{l}\text { Infor } \\
\text { man 2 }\end{array}$ & $\begin{array}{l}\text { Info } \\
\text { rma } \\
\text { n3 }\end{array}$ & \begin{tabular}{|l|} 
Infor \\
man \\
4
\end{tabular} & $\begin{array}{l}\text { Infor } \\
\text { man } 5\end{array}$ & $\begin{array}{l}\text { Inform } \\
\text { an } 6\end{array}$ & \begin{tabular}{|l|} 
Infor \\
man 7
\end{tabular} & \begin{tabular}{|l} 
Infor \\
man \\
8
\end{tabular} & $\begin{array}{l}\text { Info } \\
\text { rma } \\
\text { ng }\end{array}$ & \begin{tabular}{|l} 
Infor \\
man \\
10
\end{tabular} \\
\hline Dominan & 3 & 1 & 2 & 3 & 1 & 2 & 3 & 1 & 1 & 1 \\
\hline Negosiasi & . & 1 & 1 & . & 1 & 1 & . & 1 & 1 & 1 \\
\hline Oposisi & . & 1 & . & . & 1 &. &. & 1 & 1 & 1 \\
\hline \multicolumn{11}{|c|}{ Dominan $=18$} \\
\hline \multicolumn{11}{|c|}{ Negosiasi $=7$} \\
\hline \multicolumn{11}{|c|}{ Oposisi $=5$} \\
\hline \multicolumn{11}{|c|}{ Jumlah $=30$} \\
\hline
\end{tabular}

Sumber : Data wawancara kepada informan diolah oleh peneliti 


\subsection{Pembahasan}

Hasil penelitian yang didapatkan oleh peneliti melalui wawancara mendalam pada 10 narasumber komunitas game developer kotak kreatif - Jakarta Selatan, dari berbagai latar belakang yang berbeda dari setiap informan perbedaan ini dari segi usia, pendidikan dan pekerjaan dalam menjawab rumusan masalah yaitu bagaimana pemaknaan khalayak tentang unsur kekerasan yang terdapat pada game Among Us. Dengan menggunakan analisis resepsi stuart hall, ada 3 posisi kemungkinan yang diperoleh dari informan yang melakukan decoding terhadap pesan yang disampaikan oleh media. Tiga posisi kemungkinan tersebut yaitu posisi dominan, negosiasi dan oposisi. Hasil penelitian dengan menggunakan 30 jawaban didapatkan hasil, yaitu 18 dengan pemaknaan dominan, 7 dengan pemaknaan negosiasi, dan 5 dengan pemaknaan oposisi.

Pemaknaan dominan diperoleh saat khalayak meneriman pesan secara penuh yang disampaikan media. Dengan kata lain media menyampaikan pesannya berupa komunikasi dengan menggunakan kode budaya yang berlaku di masyarakat. Sedangkan pemaknaan negosiasi yaitu posisi khalayak yang setuju atau menerima pesan yang disampaikan media, tetapi mereka melakukan pengecualian dalam penerapannya yang di sesuaikan dengan latar belakang masing-masing informan. Dalam hal ini para informan menerima dengan positif pesan yang disampaikan, tetapi untuk ada hal-hal tertentu yang dipertimbangkan. Yang terakhir adalah posisi oposisi, yaitu khalayak menolak secara penuh pesan yang disampaikan oleh media dan menggantikannya sesuai dengan cara berpikir mereka sendiri.

Hasil pemaknaan dengan 30 jawaban mendapatkan 8 pemaknaan dominan terkait dengan unsur kekerasan yang terdapat pada game Among Us dari jumlah 18 pemakanaan dominan untuk 3 pembahasan. Kemudian pada hasil wawancara mendalam pada permasalahan kedua yakni tentang visualisasi karakter dan background game Among Us, terdapat 6 jawaban pemaknaan dominan dari total 18 jawaban dominan. Sedangkan untuk permasalahan ketiga terkait dengan alur cerita pada game Among Us, didapatkan 4 jawaban pemaknaan dominan dari total 18 jawaban dominan dari 3 pembahasan. Kemudian pemaknaan negosiasi didapatkan berjumlah 7 jawaban dari 3 pembahasan yang ditanyakan ke pada narasumber, adapun rinciannya ialah 2 jawaban terkait dengan unsur kekerasan yang terdapat pada game, 2 jawaban terkait visualisasi game itu sendiri dan 3 jawaban terkait dengan alur cerita. Selanjutnya ialah terkait dengan pemaknaan oposisi yang didapatkan hasil jawaban sebanyak 5 pemaknaan dari 3 pembahasan. Adapun rinciannya ialah 2 pemaknaan terkait dengan visualisasi dari game Among Us dan 3 terkait dengan alur cerita permainan.

\section{KESIMPULAN}

Setelah peneliti mendapatkan data-data yang diperlukan, maka peneliti mendapatkan data dan dapat disimpulkan bahwa pemaknaan (persepsi) pemain game Among Us terdapat 3 hal penting yakni unsur kekerasan, visualisasi dan alur cerita seperti yang telah peneliti jelaskan pada pembahasan. Maka dapat disimpulkan bahwa game Among Us dapat dipahami oleh khalayak baik dari segi unsur kekerasan yang ditampilan, visualisasi yang digunakan pada desain karakternya dan juga desain background selain itu dari informasi yang disampaikan yakni berupa alur cerita juga dipahami oleh para informan. Hal ini terlihat dari jumlah total pemaknaan dominan yang paling banyak yakni berjumlah 18 jawaban dari 3 permasalahan yang dibahas. Tapi walapun seperti itu, game Among Us masih dapat diterima dengan wajar oleh khalayak baik dari segi unsur kekerasan yang ada, visualisasi yang ditampilkan ataupun alur cerita yang diangkat. 


\section{DAFTAR PUSTAKA}

- Referensi dari buku

[1] Barker, Chris. Cultural Studies, "Teori dan Praktek", Yogyakarta : Kreasi Wacana. 2011

[2] Downing, John, Ali Mohammadi, Annabelle Sreberny-Mohammadi. Questioning the media; a critical introduction, New Delhi: SAGE Publications. 1990

[3] Hagen, Ingunn dan Wakso, Janet (editor). Introduction: Consuming Audiences? Production And Reception In Media Research. New Jersey: Hamton Press, Inc. 2000

[4] Kusrianto,Adi. Pengantar Desain Komunikasi Visual, Yogyakarta, ANDI. 2007

[5]. Moleong, Lexy J. Metote Penelitian Kualitatif, Bandung, PT. Remaja Rosdakarya. 2004

[6]. Putra, Ricky W, (2021). Pengantar Desain Komunikasi Visual Dalam Penerapan, Yogyakarta : Penerbit ANDI.

[7] Sugiyono. Metode Penelitian Kuantitatif, Kualitatif, R\&D, Bandung : IKAPI. 2016

[8] Tinarbuko, Sumbo. Semiotika Komunikasi Visual, Yogyakarta, Jalasutra. 2008

- Referensi dari Website

[9] https://www.thegamer.com/among-us-1-5-million-players-simultaneous-innersloth-party-game/

[10] http://www.mandalamaya.com/pengertian-game-menurut-para-ahli/ 